\title{
Article
}

\section{Petitioners and Rebels: Petitioning for Parliamentary Reform in Regency England}

\author{
Poole, Robert
}

Available at http://clok.uclan.ac.uk/17895/

Poole, Robert ORCID: 0000-0001-9613-6401 (2019) Petitioners and Rebels: Petitioning for Parliamentary Reform in Regency England. Social Science History, 43 (3). pp. 553-579. ISSN 0145-5532

It is advisable to refer to the publisher's version if you intend to cite from the work. http://dx.doi.org/10.1017/ssh.2019.22

For more information about UCLan's research in this area go to http://www.uclan.ac.uk/researchgroups/ and search for < name of research Group>.

For information about Research generally at UCLan please go to http://www.uclan.ac.uk/research/

All outputs in CLoK are protected by Intellectual Property Rights law, including Copyright law. Copyright, IPR and Moral Rights for the works on this site are retained by the individual authors and/or other copyright owners. Terms and conditions for use of this material are defined in the policies page.

\section{CLoK}

Central Lancashire online Knowledge www.clok.uclan.ac.uk

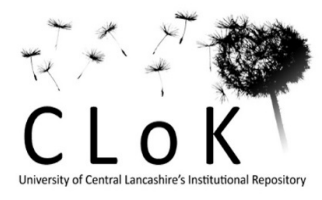


Petitioners and Rebels: Petitioning for Parliamentary Reform in Regency England

The national petitioning campaign for parliamentary reform in 1816-17 was the biggest such movement before Chartism. It generated over 700 local petitions with approaching a million signatures, representing perhaps $25 \%$ of adult males and extending the political nation well into the working classes. It was particularly strong in the Lancashire manufacturing districts, where economic grievances such as hunger and exploitation were converted through petitioning into arguments for political reform. The moving figure was Major John Cartwright, a veteran reformer who emerges as a more radical figure than usually supposed. The rejection of so many petitions by Parliament provided a legitimation for remonstrance and resistancefeeding through into the march of the Manchester 'Blanketeers' and other protests in 1817 to the mass platform movement of 1819 and Peterloo. The research combines a study of the petitions themselves and the radical press with a close examination of the Home Office material, yielding insights into both grassroots organisation and the strategies of the authorities, local and national. While the strategy of mass action was defeated by repression, the right of the unenfranchised masses to engage in political petitioning was conceded in principle long before the advent of formal democracy. 


\section{Petitioners and Rebels: Petitioning for Parliamentary Reform in Regency England}

Recent scholarship on radicalism and popular protest has moved away from the analysis of the formation and motivation of social movements in favour of dynamic accounts of their contest with power. This approach, first applied to the study of the seventeenth century, has since enriched the understanding of the industrial revolution period. (Thompson 1991; Harris 2001; Wood 2002). Constitutionalism has replaced class as the dominant narrative of England's abortive age of revolution (Epstein, 1994; Vernon, 1996). While studies in this area have much to say about language and culture,they have had little to say about the practical business of petitioning. . Yet petitioning was the core activity of radical politics in the post-war years. This article will argue that the mechanism that gave English social and economic protest its political cutting edge in 1816-17 was not the strike or the riot but the petition.

Petitioning as a radical tactic dated back to the civil wars of the 1640s. Jason Peacey argues that early modern petitioners who placed their hopes on the newly assertive parliament found that "petitioning was frequently frustrating rather than empowering", leading to a shift in the tone of petitions from supplicatory to "increasingly demonstrative and even aggressive".. The product of this process of “experience-led bottom-up political thinking” was radicalism (Peacey 2016: 165). Brodie Waddell suggests that the main advantage of petitioning was in publicizing grievances (Waddell 2016). A year after the Restoration of the monarchy, the 1661 Act Against Tumultuous Petitioning prohibited petitions to king or parliament signed by more than twenty people (only ten of whom might present it) unless approved by three magistrates, a grand jury or the city of London authorities. The 1689 Bill of Rights declared that: "It is the right of the subjects to petition the king, and all commitments and prosecutions for such petitioning are illegal." The Bill of Rights 
was widely assumed to have nullified the 1661 Act and enshrined the right to petition Parliament as well, although at the trial of Lord George Gordon in 1780 Lord Mansfield ruled that it had not (Manchester Observer, 17 January 1818; Knights 2012: 60). Reformers however liked to cite Blackstone, who wrote that in defence of their rights, where the courts had failed them, 'the subjects of England are entitled . . to the right of petitioning the King and Parliament for redress of grievances; and, lastly, to the right of having and using arms for self-preservation and defence.' (Pearson 1820: 5). While it was popularly believed that the right to petition encompassed the right of assembly (Handley 1986; Bradley 2007), the 1795 Seditious Meetings Act restricted the right to meet "for the Purpose or on the Pretext" of discussing any petition (or similar document) to the monarch or Parliament, on issues relating to Church and State. Political meetings of over fifty people had to be called by the county or borough authorities, or approved by two magistrates or a grand jury. Meetings had to be locally advertised at least five days in advance, on notices signed by at least seven householders, or they became "unlawful assemblies" liable to be dispersed under the provisions of the Riot Act. The Seditious Meetings Act expired in 1798, leaving the 1661 Act as the main restriction on the right to petition.

The right to petition and its practice was shaped by the dynamic contest between the state and radical movements. Opposition petitioners proclaimed their breadth of support and weight of numbers while government supporters insisted upon on the need for legitimacy, demonstrated by petitioners of suitable status acting under lawful authority (Zaret 2000; Bradley 2007; Knights 2009; Knights 2012). Petitions became more numerous in the 1770 s and 1780 s, while the practice of receiving them became more restrictive, leading to a series of incidents involving frustrated petitioners (Poole 2000: 27, and chapters 1-2). During the Napoleonic wars (1803- 
1815), issues of trade were politicized. Large-scale petitioning campaigns, first against the slave trade and then against the economic blockade of continental Europe, mobilized middle-class opinion. Decades before parliamentary reform, petitioning extended the political nation well beyond the formal electorate. Late eighteenthcentury petitions for reform from parliamentary boroughs were often signed not just by "freeholders" but by "inhabitants". Non-electors typically made up around half the total signatures, indicating a political nation of some 450,000 - two to three times the parliamentary electorate, at least in the boroughs. (Phillips 1980; O'Gorman 1989: 285-300).

This process spread further down the social scale as workers took up petitioning as a means of dealing with the disruption of their trades by industrialisation, war, and economic deregulation. The state economic policy of laissez-faire seemed to favour capital over labour, systematically removing protection from workers while banning trade union activity through the Combination Acts of 1799-1800. After the war, Parliament repealed the property tax following extensive middle-class petitioning but left in place the indirect taxes on articles of working-class consumption. The Corn Law of 1815 virtually prohibited grain imports, raising prices and favouring producers over consumers. The post-war slump, compounded by the catastrophic harvest of 1816, threatened the livelihoods and even the lives of ordinary citizens. How far could a parliament be said to represent "the people" when it treated them thus? Radicals made rapid headway with the argument that, even for the poorest, the route to economic justice lay through parliamentary reform.

\section{Petitioning for redress}

For some time petitioning over economic grievances, making little impact, had been feeding through into demands for parliamentary reform. In the 1790s Lancashire's 
commercial and manufacturing interests were predominantly loyalist, careful while asserting the economic interests of their trades to defend the political status quo (Navickas, 2009). In May 1799, the Lancashire Association of Weavers appealed to the public that "we ... are firmly attached to our King and Country ... We shall neither interfere with church nor state, but strictly confine ourselves to a private grievance." While expressing support for the recent Seditious Meetings Act, the weavers insisted that it did not restrict citizens from lawfully petitioning government in their own private interests: "we are determined that those who are appointed by the constitution of our country to redress our grievances, shall have our real state laid before them; and it must be their wisdom that must determine this point" (Radcliffe 1828: 73-6). The weavers presented themselves as a corporate body, making legitimate representations on behalf of their trade to government.

In 1816 the weavers of Stockport, a cotton town south of Manchester, were initially inclined to be deferential. In May, with rates for weaving down to a quarter of what they had been and weavers earning only four or five shillings a week, the Stockport weavers' leaders approached the Reverend Prescot, the local magistrate, to call a public meeting to petition the Commons for "such redress as the House might think fit to afford". Prescot was receptive to their concerns but unhappy about their mode of proceeding:

I recommended their sending the Petition immediately to the chambers for Cheshire, as much time might be lost by going about for probably fifteen thousand signatures, \& the inconvenience that attend large meetings be prevented. I trust the small number of names will not prevent the petition being attended to, or its going into a Committee. 
Many families are in a starving condition, numbers are \& more will soon be out of work, they are almost driven to despair, the symptoms of intended rioting are stronger than, I recollect they were previous to the breaking out of the Luddites.

At Prescot's suggestion, the weavers submitted their petition to him, together with a covering letter setting out the extremity of their poverty. Prescot forwarded it approvingly. His clerk, the hawkish Tory John Lloyd, commented: "It is temperate humble \& true and attention will be flattering if not effectual". Lloyd set about organizing poor relief, whilst simultaneously enrolling special constables and prosecuting the distributor of an inflammatory handbill. Four days later Prescot was able to tell the Home Secretary, "The Weavers are pleased with their petition having been presented on the day of its arrival." Nothing, however, came of it. Similarly, appeals from destitute weavers in the Bolton area were forwarded to government by the local magistrates of Bolton, the deputy lieutenants of Lancashire, and the Lord Lieutenant, Lord Derby. Once again the authorities supported the weavers' account of their own distress but pointedly not their request for trade protection, at the same time beefing up the military presence in the area. Respectful appeals for the relief of distress elicited a show of paternalistic intercession, but political demands provoked a show of force. ${ }^{2}$

The key figure in channelling popular economic grievances into a petitioning campaign for parliamentary reform was Major John Cartwright, a veteran reformer who had advocated the principle of manhood suffrage ever since the American War of Independence. Cartwright chose to argue his case in public with reference to England's “ancient constitution", dating back to Anglo-Saxon times, which he claimed had been founded upon the right of all (male) inhabitants to vote. This 
allowed English reformers to adopt a patriotic and constitutionalist position, sidestepping the problems posed in wartime by supporting the French model of revolution. In 1812 and 1813, in the aftermath of the Luddite risings, Cartwright had toured the northern manufacturing districts under the aegis of the short-lived Union for Parliamentary Reform and founded dozens of local Union Societies. (Miller 1968; Cartwright 1826: 45-47; Eckersley 1999: chapter 6). The summer of 1816 saw the independent establishment of a third wave of societies, particularly in the Manchester region.

In August 1816 Stockport's reformers twice called upon the Rector to request a formal public meeting to petition the Prince Regent to recall parliament to deal with the distress. Lloyd posted his son to report on their meetings.

Several Voices called "Damn the Rector - we have as much authority to call a Second Meeting as we had to call this - we may wait for ever if we wait for him - he will order us Soup!” ... They had better begin themselves - They might as well be hanged as starved - If fair means wou'd not do they must use force. The Livery Men in London were no trifling People they had exercised their rights \& privileges and set an example how to act. ${ }^{3}$

The sentiment "rather be hanged than starved" was a familiar food rioters' slogan. (Bohstedt 2010). It now lent the legitimacy of despair to radical political demands. A pamphlet, Petitioning Weavers Defended (published in Manchester in January 1817) insisted that petitioning was a constitutional procedure. "Is it not the common mode of proceeding, to send delegates with petitions to watch their progress, and to assist in every legal way?" The poorest weavers, claimed the writer, paid half their income in indirect taxes: "Now only trace the money thus paid, to the pocket of the sinecurist, 
and you may have one instance where the 'corruption and misconduct of Government' are the causes of 'privations and distresses' to the weaver." ('Operator' 1817).

Lloyd denounced the Stockport delegates as agitators guided from London and threatened them with prosecution under the 1661 Act. "I would rather wish to prevent a call upon the Rector by any Requisition and that is my reason for publicity", he told the Home Office. ${ }^{4}$ He put up posters stating that any petition to Parliament signed by more than twenty people had to be approved by three magistrates or a grand jury under the terms of the 1661 Act. The liverymen of London, whose petitions in the name of the City Corporation were held up as an example by the Stockport reformers, were, he explained, exercising corporate privileges, not general rights. "Old Cartwright has got his agents at work", explained Lloyd to the Home Office as he requested troops. "The Reformists enjoin the people to abstain from violence or outrage as tending to defeat their ends. But the fear is that an ungovernable and unruly spirit may be engendered by brooding in concert over calamity - which may burst forth suddenly." 5

Further contests of legitimacy followed. In September 1816 Bolton's reformers successfully requisitioned the boroughreeve to hold an official town meeting to discuss local economic distress. Held outdoors with the boroughreeve's sanction this assembly of 2,000 to 3,000 inhabitants passed resolutions for parliamentary reform, and to petition both Parliament and the Prince Regent for "a fair, equal, and constitutional representation of the People". The loyalist magistrate and spymaster Ralph Fletcher was aghast. The requisition for a meeting had been got up without authority by "the disaffected part of our peace officers" rather than by "the respectable part of the inhabitants". While similar meetings had been held in several other towns, only in Bolton had the authorities given their approval. The failure to get 
permission from the magistrates, Fletcher claimed, made the meeting illegal under the 1661 Act Against Tumultuous Petitioning. Lloyd also complained that the resolutions were approved by a mere show of hands 'altho' I declare that not a third of the assembly heard them". The deputy constable who presided should be sacked. ${ }^{6}$ When in October anonymous fliers advertised a public meeting in Stockport for "parliamentary reform", an exasperated Lloyd had them pulled down and posted counter-notices declaring the meeting an unlawful assembly under the terms of the 1661 Act. The reformers responded with a longer notice signed by 33 inhabitant householders, insisting on its legitimacy. ${ }^{7}$ Even greater embarrassment followed at a formal county meeting in Preston in February, when a loyal address to the Prince Regent deploring unrest and sedition was amended to blame the unrest on distress and to demand a change of government. A face-saving minority motion claiming a preponderance of nobility and gentry in favour of the original was hastily cobbled together, reinforced by 3,000 signatures to convey an impression of consensus. While the majority motion was formally presented to the Prince Regent by the Lord Lieutenant and county MPs, the minority one was ceremoniously presented by the high sheriff at a levée. ${ }^{8}$

These contests over public meetings reveal two competing interpretations of the right to petition: a radical one appealing to popular sovereignty, and a conservative one based on law, residence, and property. The contest, described by one local magistrate as "a Conspiracy of Persons not having Property against those who have", was played out most prominently in Manchester, a fast-growing commercial and industrial town run by a Tory-dominated parish vestry, manorial court and police commission. ${ }^{9}$ In October 1816 what the indignant boroughreeve called "a large 
flaming placard" was posted in the town, signed by upwards of two thousand householders.

PUBLIC Meeting.

The Boroughreeve and Constables of Manchester, having declined to call a Public Meeting, to take into consideration the present deep and general Distress, its primary Cause, and radical Remedy; although solicited so to do, by about FOUR HUNDRED Inhabitant Householders; therefore we, the undersigned Inhabitant Householders of Manchester, deeming such a Meeting highly necessary, do hereby appoint a MEETING for the above purpose, to take place near St PETER'S CHURCH, on MONDAY the $8^{\text {th }}$ day of October, 1816, at ELEVEN o'Clock in the forenoon. ${ }^{10}$

The radical weaver Elijah Dixon later explained: "A Number of us considered a Parliamentary Reform was highly necessary therefore we signified the same to the Public \& desired the Boroughreeve to call a Meeting to Petition Parliament for a Reform and some Redress for the Grievances ... seeing no People of Property came forward they declined having anything to do with it, so about the $28^{\text {th }}$. Sept ${ }^{\mathrm{r}}$.... we had borne it long enough \& we thought it high time for something to be done."11 The Whig MP George Philips later argued in the Commons that this was a perfectly legitimate procedure, as their request had been rejected by the town's officers (Hansard 9 February 1818: 217-32). The meeting resolved to establish the Manchester Constitutional Society and to petition the Prince Regent for "a full, free and equal Representation in the Commons House of Parliament, annually elected."12

Local skirmishes over the right to petition and right of assembly paved the way for a national confrontation between radicals and the state, played out between 
November 1816 and June 1817, which was to shape the future of mass petitioning and extend the boundaries of popular politics.

\section{Petitioning for reform}

William Cobbett's mass-circulation Address to Journeymen and Labourers, published in early November 1816 to promote reform, urged its readers:

Petition is the channel for your sentiments, and there is no village so small that its petition would not have some weight. You ought to attend at every public meeting within your reach. You ought to read to, and to assist each other in coming at a competent knowledge of all public matters. Above all things, you ought to be unanimous in your object, and not to suffer yourselves to be divided.

At the same time the London Hampden Club, an elite reforming lobby group with a property qualification of $£ 300$, of which both Cartwright and Cobbett were members, launched a national petitioning campaign. On 2 November it drafted a bill for 'parliamentary representation of the same extent at least as direct taxation', with equal electoral districts and annual parliaments. This bill would be submitted to a national meeting of delegates from the petitioning towns, to "be rendered as unexceptionable as possible, before it be finally submitted to Parliament", around March $1817 .{ }^{13}$ This plan was essentially Cartwright's, and he elaborated it in his pamphlet A Bill of Rights and Liberties, which proposed a redistribution of seats according to population in which Lancashire would elect 41 MPs instead of the current 14. Members would be nominated each year at a local "folkmoot" held on the anniversary of Magna Carta (15 June). If a ballot were necessary, “every male commoner" old enough to do militia service would vote. (Cartwright 1817a). 
Cartwright's innovation as a campaigner had been to replace the traditional single petition roll with smaller printed sheets, making collection quicker and more flexible.. (Miller 1968; Miller 1974; Cartwright 1826). He claimed to have collected 199,000 signatures for parliamentary reform this way on his 1813 tour, but it is obvious that this deep extension of political petitioning into the unenfranchised classes provoked significant resistance from above. (Cartwright 1826: 59-65). All he received of a 30,000-signature petition from Manchester was a few mangled sheets and a note from John Shuttleworth explaining that it had been destroyed 'in consequence of the apprehension which the conduct of the police [\&] magistrates had occasioned, that there was great personal danger in being concerned in it'. ${ }^{14}$ There were also reports of seizures, and at least one arrest, from Bolton, Rochdale, Salford and Glasgow. Preston's Whig MP, Lord Stanley, refused to present the town's ten petitions to the House. A briefer campaign in the spring of 1815 , this time without a personal tour, reportedly brought over five hundred petitions to Cartwright's home, though these seem to have been much smaller. (Cartwright 1826: 59-96, 111) A copy of one of the printed petition forms from late 1816 survives in the National Archives, part of a consignment of 100 brought to Manchester by Cartwright's Lancashire contact Joseph Mitchell. It was obtained by a spy and taken to Captain Chippendale of the Oldham Local Militia who forwarded it to the Home Office. The preamble, printed across a wide sheet, began with the provocative claim:

That your Honourable House doth not, in any constitutional or rational sense, represent the Nation:

That when the People have ceased to be represented, the Constitution is subverted:

That Taxation without Representation is a state of Slavery. 
This state of affairs was attributed to a combination of the prolonged wars against France and "the usurpation of a Borough Faction". Foreseeing that "the unrelenting lash of unconstitutional Taxation may, in all time to come, be laid on to the utmost extent of human endurance" the petitioners demanded that "their sacred rights of Election" should be restored: at the minimum a taxpayer franchise, "an equal distribution, throughout the Community, of such Representation", and annual parliaments. ${ }^{15}$ The large petition forms were offered for sale by a radical London printer at one shilling and sixpence each.

This form of petition had in fact been approved by the Hampden Club on 4 March 1815 "to be proposed in Meetings of Counties, Parishes, or Districts; or otherwise tended for the Signatures of such as may approve the same." It was conceived as part of a wider political strategy.

It seems far more proper that Petitions for the present object should be every where made as easily accessible to the People as possible, rather than that they should be proposed in General Meetings of large cities or counties, which very few in comparison can attend.

And, Sir, it is peculiarly fit and desirable, that such persons as are in too indigent a situation (much of which has been the consequence of misgovernment) to be subject to "direct taxation," should nevertheless be freely allowed to sign Petitions. Which only pray that persons so taxed shall have votes in elections, while themselves are excluded. ${ }^{16}$

The 1816 petition form demonstrates this open strategy. It was "printed at the head of large sheets ruled for the reception of signatures," of which "an immense number" arrived for distribution in Manchester. ${ }^{17}$ But while it was usual for petitions to carry 
headings for the address, status or occupation of the signatories, the ruled spaces below this one were blank: men were to sign simply as citizens.

The campaign of 1816-17 was given a more militant character by two mass meetings at Spa Fields in the north of London in November and December 1816. The notice for the first advertised "a Meeting of the distressed Manufacturers, Mariners, Artizans, and others, ... to take into consideration the propriety of petitioning the Prince Regent and Legislators to adopt immediately such measures as will relieve the sufferers from the misery which now overwhelms them." The meeting was organised by the ultra-radical London Spencean society, which persuaded the popular orator, Henry Hunt, to chair it. The resolution passed on the day was not to petition Parliament but to remonstrate directly with the crown for the dismissal of the government. Militants wanted to march from the meeting to confront the Prince Regent en masse, but Hunt instead carried a motion to present the remonstrance through ministers, and to reconvene on 2 December to hear the outcome. Hunt claimed that when he brought the document to the Home Secretary, Lord Sidmouth, he had already received from the local magistrates a copy of a more inflammatory draft that had been rejected. (Commons Journal [CJ], lxxii. 102-3). Hunt reported to the reconvened meeting on 2 December that the Regent had declined to receive the remonstrance and had instead donated $£ 4,000$ to fund a soup kitchen in nearby Spitalfields. He then steered through a resolution to petition Parliament en masse for reform. Parliament would back down, Hunt claimed, when they understood that this time "the whole people of England were petitioning for their rights", and he proposed that "the whole of us shall sign it". The resolution passed, and the meeting resolved to reconvene soon after parliament met to receive the result. An attempt by a militant faction of the Spenceans, before Hunt arrived, to lead part of the crowd to storm the 
Tower of London confirmed the government's view that the entire petitioning campaign was a cloak for insurrection. Belchem identifies the Spa Fields meetings as the beginning of the "mass platform" strategy, which sought to swing an overwhelming force of numbers from across the country behind a metropolitancentred constitutional campaign for parliamentary reform. The crucial question for the petitioners, as for the later Chartists, was what would happen when the petitions were rejected. (Chase 1998: 84-87; Belchem 1985: 44-50).

Among the provincial reformers at the Spa Fields meeting had been Joseph Mitchell, Cartwright's Lancashire contact, whose own views were close to those of the Spenceans. Mitchell had no faith in petitioning a corrupt Parliament, and his own Address to the People (published a month before Cobbett's more famous one) consisted mainly of a long ultimatum to the Prince Regent. ${ }^{18}$ Many in Lancashire shared his views. In early September an agent reported on a speech by the Royton radical William Fitton at a meeting on the edge of Manchester. At first Fitton "spoke in terms of great moderation", but then, "Speaking of the mode by Petition he strongly recommended that as the most prudent first Step, but if that should prove ineffectual then!!!! At this Point he made a full Stop. After a considerable Pause a Person in the Crowd called out 'what then?' To this no Reply was made except a significant Smile by the Roytonians."19 Two days after the second Spa Fields meeting, which came at the end of a bitter strike of Lancashire weavers, there were rumours in the Manchester area "that the Bank was destroyed and the Tower surrendered to the Insurgents.” Agents reported crowds of people on the roads to Manchester:

About midnight they began to draw towards Manchester for the Purpose of learning the news brought by the Mail. My Informant saw three Hundred in one Group in a street adjoining to the Bridgewater, where the mail stops, all 
Delegates from the Country. When the news was not confirmed their disappointment was extreme. ${ }^{20}$

Similar excitement was reported from other parts of the country (Chase 1988: 85-6).

Mitchell, returning from London with the petition forms, attended the weekly radical open meeting in Manchester on 9 December. He read a letter from the radical Whig MP Sir Francis Burdett saying that the earliest date the Prince Regent would grant an audience was 2 March, which the meeting considered was too long to wait. A poster advertising a public meeting to be held on 16 December at Middleton, a radical weaving village north of Manchester, outlined the radicals' next move:

To take into consideration the awfully alarming distress which overwhelms our Country, and to recommend to Major Cartwright, Sir Francis Burdett, \&c. to prepare forthwith, a Draft of a Bill for Parliamentary Reform, and to submit the same to the Deputies of the Petitioning Bodies, before Parliament meets, as it is impossible for the People of this part of the Country, to SUBSIST on their present means, even with the support of the SOUP KETTLE, till the Date fixed by the London Hampden Club, (March $2^{\text {nd }}$ ) - and also for the purpose of moving a Petition ONCE MORE to the House of Commons, for such a Reform. ${ }^{21}$

This meeting resolved to press the Hampden Club to prepare both the petitions and the reform bill for the opening of Parliament, and voted to send out four missionaries to Cheshire and Yorkshire to visit "the most populous neighbouring towns which have not yet held meetings for parliamentary reform." 22 A printed circular appealing for funds described their aim as "to instruct and assist those places . . . how to break through their local restraints, and urge them to forward their petitions to the House of Commons."23 
The petitioning process raised high expectations, as the Oldham militia captain William Chippendale reported.

The leading men in the provincial Societies are busily employed in going from House to House to get Signatures on their Petitions. In the form which they use for this Purpose is a Column in which they return those Men who are willing to join the Union in Case of a Convulsion, and who are stout and ablebodied and able to bear Arms. ${ }^{24}$

There was also an ominous "black Book" for the names of those who had refused to sign and who would be "the first Sacrifices when the great Rising took Place." When George Holmes, a local surgeon, refused to sign a petition he received a note from "A Reformer" warning him he would be "a marked man" if he did not. Shortly afterwards he attended what turned out to be a fake call and returned to find that his stables had been set on fire. ${ }^{25}$ In Warrington, a sheet from a petition bearing some 350 signatures was seized by one Richard Burrows on 22 January, “as a joke”. Burrows was rescued from an angry crowd by the authorities and the petition impounded by Thomas Lyon, a special constable and former magistrate, who refused to give it up. The petitioners complained to the House of Commons that this constituted "not only a gross attack on the right of the People to petition, but also a high breach of the privileges of the House ... who alone have the right to determine whether the said Petition should be received." Lyon was summoned before the House and obliged to apologize, claiming in his defense that the petition "had been handed secretly about the town for signatures by some obscure individuals; and ... by various arts and false representations, many persons, including very young boys at school, had been induced to sign the same." (CJ, 1xxii. 27, 65-66). ${ }^{26}$ Such disputes dramatized the conflict at the core of political petitioning, between the right of the authorities to 
control what could be done in the name of the public, and the right of the public to petition Parliament freely.

On 30 December the London Hampden Club agreed to submit the petitions and reform bill to parliament as soon as it met in January, and arranged an extraordinary general delegate meeting to decide the content of the proposed reform (Hampden Club 1822). Lancashire reformers had firm ideas as to what that content should be. On the same day a meeting of Manchester reformers voted in favour of "representation co-extensive with taxation," meaning indirect taxation — in effect, manhood suffrage. Meetings at Middleton and Oldham shortly afterwards both voted explicitly in favour of universal suffrage. All three meetings then adjourned until after the opening of Parliament to receive news of the fate of their reform bill ${ }^{27}$ It was reported that some friendly society and sick club boxes had been broken up to provide funds to send delegates, expecting that there would be no need for such relief after parliament had been reformed (Lockley 2013: chapter 3). ${ }^{28}$

\section{Petitioning by delegation}

The next stage was to select delegates from the petitioning towns to go to London. The aim was to send fifteen from the Manchester region, and despite an acute shortage of funds there were thirteen -a quarter of the national total. Chippendale listed eleven delegates sent from his neighbourhood east of Manchester, including five weavers, two shoemakers, a bankrupt tailor, a failed cotton manufacturer, and two involved in the press - classic artisan and activist backgrounds. ${ }^{29}$ Three of them Mitchell, Benbow and Fitton - had been among the missionaries. The Morning Chronicle (23 January 1817) characterised the delegates generally as "the Deputies of manufacturing districts, and from the very worthy class of mechanics in towns." There were, reported The Times (24 January 1817), between forty and fifty present at 
the national delegate meeting on 22 January at the Crown and Anchor tavern in London, “principally from Bristol, Bath, Leicester, Bolton, Glasgow, Royston [Royton], Loughton, Stockport, Lynn, Norwich, Ashton-under-Line, Leigh, Lancashire, Manchester, Middleton, Spafields, and Mr. Home from Liverpool.” The radical Manchester Political Register (1 February 1817) claimed that the delegates represented 150 towns, including 34 places in the Manchester region.

At the start of the meeting the delegates handed in their credentials or "vouchers". The silent implication was that the meeting was more representative of the people than the House of Commons, although the organizers were careful not to present it as a constitutional convention or anti-parliament (Parsinnen 1973). Cartwright explained that the meeting had not been called by the Hampden Club itself but by "some friends to the cause of reform" who would report back to the club. The delegates debated the proposed reform bill, which was for household suffrage, annual parliaments and the secret ballot. Both Cartwright and Cobbett, while in principle in favour of universal suffrage, argued that household suffrage was the practical limit, but Samuel Bamford of Middleton argued that the rolls of those eligible for militia service could provide the electoral register: "I see no reason why regulations, which have been put in force universally for calling us forth to bear arms in the defence of the country and of the estates and property of the country, should not be put in force again, and by the very same officers, for calling us forth to exercise our right of suffrage at elections." Cobbett was persuaded and the vote went in favour of universal suffrage. (Cobbett's Weekly Political Register, 22 February 1817; Bamford 1844: chapter 4). Thanks to the petitioning campaign the voice of the Lancashire weaving districts proved decisive in the national debate.

The radical Whig MP Lord Cochrane agreed to present the bill and the first petitions. A few days later, as Parliament opened for business, Hunt and his supporters called at Cochrane's house, where "a large petition from Bristol, and most 
of those from the north of England, were placed in his lordship's hands." Hunt unrolled the Bristol petition for effect, and Cochrane was chaired to the entrance of Westminster Hall by an enthusiastic multitude. (Author 2009; Huish 1836: 30-42; Bamford 1844: chapter 4; Cartwright 1826: 126-7)

\section{Petitions in Parliament}

On 29 January 1817 Cochrane presented eight petitions for parliamentary reform to the Commons. All stressed the privations of the people, which were attributed to high taxation and wasteful public spending. They identified the root cause as a monopoly of political power by a self-interested elite and the root remedy as parliamentary reform. The largest petition, from Bristol, carried 15,700 signatures and was ordered (in the customary rebuff) to "lie on the table". "How much more in character would it be if a shelf were put up in each house," complained Bamford. "The honoured applicant would then be understood when he said that his petition was "shelved." (Bamford 1844, II: chapter 10). The other seven were all from the manufacturing districts east of Manchester, reflecting the distribution of delegates. The petition from the township of Quick in Saddleworth began with a long complaint incorporating the Hampden Club petition's phrasing "that the House doth not, in any constitutional or rational sense, represent the nation; that, when the people have ceased to be represented, the constitution is subverted" (Hansard 29 January 1817: 81-3) It went on to complain of the "repeated, protracted, and disgusting debates" of the Commons. It was rejected for its insulting language, as were similar petitions from Delph and Ashton-under-Lyne, while Cochrane withdraw another from Castleshaw. The Tory MP William Wynn complained that "the whole tenor of the petition maintained that that House did not, in any constitutional sense, represent the people ... [was] utterly inadmissible at any time or under any circumstances." The cabinet minister George 
Canning went further: "to assert, that the constitution had been subverted ... was no longer the language of petition; it was a direct excitement to rebellion" (ibid., 85-6). Petitions from Oldham and Lees, using strong language about corrupt taxation, were however received to "lie upon the table". Another petition from Oldham was disallowed because the signatures were not attached. The House set a deadline of 14 March for petitions to be submitted, and 24 March for them to be read in the House. By that time 704 petitions for parliamentary reform had been submitted from across Great Britain. By 20 May, when Burdett's motion for a Select Committee on the state of representation triggered a final debate, there had been fourteen more, making 718 in all. They came from 346 towns, 280 of them from Lancashire, Cheshire, Yorkshire and the East Midlands, mainly from the textile towns and manufacturing districts. (Cannon, 1972, 167-74).

It is difficult to judge the overall numbers of signatures, which were not systematically recorded by Parliament before 1833. At the Crown and Anchor meeting on 22 January Hunt claimed that "nearly 600,000" had already been collected, including 100,000 from London alone (The Times, 24 January 1817). The Whig Henry Brougham talked of half a million signatures on 7 February, by which time only 42 petitions had actually been submitted. (Hansard 7 February 1817: 250-1). When Burdett presented the biggest single batch of over 500 petitions on 3 March he claimed there were nearly a million signatures (Hansard 3 March 1817: 859). By 20 May, with 718 petitions submitted, Burdett was able to claim that they came "from every part of the country, bearing not less than a million of signatures." (Hansard 20 May 1817: 706). The highest estimate reported was by Francis Place: one-and-a-half million signatures on 524 petitions by 12 February. ${ }^{30}$ The numbers of signatures were reported for only a few individual petitions: 15,700 signatures were claimed for the 
Bristol petition presented on 29 January, 5,000 and 300 for two petitions from Cornwall on 31 January, "thousands" for the Norwich petition of 4 February, and 30,500 or "nearly 40,000" for the Manchester petition of 6 February.(Cartwright 1826: 127-8). Hunt had earlier claimed 14,000 for Bristol and 8,000 for Bath. A petition from "the people of Hampshire" was signed at a meeting of some 20,000 people on 10 February and presented to the Commons the next day (CJ, lxxii. 46-8). Hunt stated that the Spa Fields petition, presented after the third meeting of 10 February, had 20,000 signatures at the time of the second meeting in December ( $C J$, 1xxii. 102-3; The Times, 24 January 1817). (CJ, lxxii. 27). These nine petitions alone had a reported 120-150,000 signatures.

We can arrive at a credible overall total by looking at the average size of previous petitions. The 292 petitions with 199,000 signatures which Cartwright had collected on his 1813 tour averaged 618 names each. At that time organisation was much weaker, and petitioners had been subject to seizures, arrests and intimidation. (Cartwright 1826: 51-2, 59-65) The previous high point of petitioning, the 1814 antislavery campaign, generated 800 petitions with some 750,000 signatures in all, averaging nearly a thousand each. (Knights 2009: 48) The size of petitions seems to have been growing; the Bristol reform petition of 1815 had 11,000 signatures, that of 1817 15,700. Preston had supplied 2,503 signatures spread across ten petitions in 1813 , and it is unlikely that the two petitions of 1817 totalled any less (Cartwright 1826: 59-65, 111). An estimate of at least 750,000 signatures from the 718 reform petitions seems reasonable, and Burdett's claim of a million (which implies an average of 1,400 signatures per petition) may not have been far out. The population of Great Britain in 1816 was approximately thirteen million, no more than a quarter of them adult males, so the radical campaign of 1817 by this estimate could have 
mobilized between $23 \%$ and $30 \%$ of adult males (although there were reports that some had been signed by youths). This was at least double the electorate at this time (around 400,000), and approximated (albeit at a lower social profile) to the $25 \%$ of adult males who constituted the pre-Reform "political nation" (Philips 1980: 624-5; O’Gorman 1986; O’Gorman 1989: chapter 4). In the manufacturing districts signatories may well have been in the majority, dwarfing the parliamentary electorates. It is comparable with the first Chartist petition of 1839 , which gained 1.2 million signatures in a population of around 18 million.

The deluge of reform petitions caused debates over the legitimacy of mass political petitioning. The arguments were aired on 4 February when the petition from Norwich was presented by the city's MP, who argued that "there must be very strong language indeed in a petition, before he could be induced to decline to present one from his constituents" (Hansard 4 February 1817: 202-3). The Foreign Secretary and Leader of the Commons, Lord Castlereagh, objected that while "the feeling of the House must ever be in favour of receiving petitions", members were not obliged "to submit to every insult that the wicked imaginations of designing men might be pleased to heap upon them" (ibid., 205-6). The Speaker agreed and the House declined to receive the petition (ibid., 205, 208). Thirty-four of these insulting petitions, including the Manchester one, used the Hampden Club wording, first used in the Quick petition. When Cochrane presented the first Manchester petition he argued that while it contained strong language "there was nothing in it very violent or obnoxious" (Hansard 6 February 1817: 234). Brougham noted that the most objectionable passage about the "tedious and disgusting debates" of the House had been removed, making the petition acceptable (ibid., 235-6). The Chancellor of the 
Exchequer, Nicholas Vansittart, however found a new passage about "the unrelenting lash of a taxation" offensive, and the petition was rejected by 50 votes to 17 (ibid., 236, 238). The next day however another petition from the inhabitants of Manchester and Salford for universal suffrage and annual parliaments was received, despite a long and aggressive preamble prophesying "the annihilation either of the Government or of the People" (CJ, lxxii. 36-7). [CONTINUE SAME PARAGRAPH HERE]The petition from the third Spa Fields meeting, presented on 11 February, declared:

That to meet for the purpose of petitioning the King, or either House of Parliament, is a right expressly secured to the People by the Bill of Rights; that the Right of Petition is in that great Constitutional Law, declared to be the birthright of the People of this Land.

James II, it was claimed, had been expelled for "having violated the right of Petition". Despite this explicit threat to the crown the House prudently decided not to challenge Londoners' right to petition, and the Spa Fields petition was received (ibid., 45-6). In general, the House seems to have been sensitive to the right to petition, baulking only at direct insults that questioned its own legitimacy.

The radical Manchester Political Register kept its readers informed of the progress, and demise, of their petitions (Manchester Political Register, 8 February 1817). Organizers responded rapidly to rebuffs by seeking to adapt their petitions. On 6 February Chippendale reported:

Several Petitions from this neighbourhood have been rejected viz. Saddleworth Failsworth \&c.... and have been sent down for Amendment. This operation is performed by cutting off the old Petition and attaching a new one to the same Names. No application has been made to those who have signed the old Ones to obtain their Sanction but all their Ingenuity is exercised in 
patching the different Parts together so as to evade Observation and give it the Appearance of being original. ... Whenever a Petition has been prepared that contains Language similar to one that has been rejected, this Deception is practised. ${ }^{31}$

A second petition from Saddleworth was presented to the Commons on 11 February, indignantly complaining about the rejection of the first petition and of "corruption ... as notorious in the House as the sun at noon-day", but without the offending wording it was received. (CJ, 1xxii. 48-9). Reformers demonstrated their faith in the right to petition by attention to constitutional proprieties.

The presentation of the bulk of the petitions on 3 March was a piece of theatre. Hackney carriages were hired to get them from Cartwright's residence at Birmingham Gate to the Palace of Westminster, including the 'great gun' from Manchester with its thirty thousand signatures (Eckersley, 1999, 222-3). They were presented to the House by Burdett(all quotes from debate from Hansard 3 March 1817: 859-63).

Sir F. Burdett said, he was intrusted with the presentation of certain petitions for a reform in parliament, about 600 in number, and signed by nearly a million of individuals. He would not occupy the time of the House by attempting to particularize these petitions, but would merely move that they be brought up.

The Speaker -Are they all to the same effect?

Sir F. Burdett replied in the affirmative, and proceeded to the floor, near the table, which was strewed for a large space with these petitions. On the question that they be brought up, a laugh was caused by the difficulty in which the hon. baronet was placed, owing to the great mass of these petitions. Sir 
Francis, assisted by the clerks, went through the labour of lifting the petitions upon the table.

Cochrane and Burdett then selected a few sample petitions, particularly from Lancashire and Scotland, to be formally "laid upon the table", the rest to be received en bloc. The Speaker of the House commented that "the practice of bringing up many petitions at once, had become common, but this night it had been carried to an unprecedented extent." Burdett excused himself from the labour of reading so many petitions, adding that "a printed petition might express the sentiments of the people as correctly as if it were written" (ibid., 861).

The Habeas Corpus Suspension Act was just about to be signed into law, and the House prudently adjourned the debate until 12 March, by which time emergency powers were in place and the march of the Manchester Blanketeers towards London had been intercepted. The House emptied, leaving only 64 members and causing Sir Gilbert Heathcote to exclaim: "On a day like this, when it was known that upwards of 500 petitions were to be considered, what was the situation of the House? Most of the gentlemen had retired to take their dinners very comfortably, and the petitions of the people were treated with contempt." The House voted to receive eleven of the petitions and reject 502, with only six members dissenting. ${ }^{32} 468$ of these were refused en bloc because they were printed, including 53 from Lancashire. Over the whole four months 209 reform petitions were received and 509 refused: the 468 printed ones, four because the signatures were detached, and 37 for insulting language. Cartwright argued that the rule against printing had only been applied as recently as 1813 , when some of the 
printed petitions he had collected were rejected. But this ruling cited an earlier ruling of 1793 , which in turn cited only a resolution of 1656 by a "mock parliament of the usurper, Cromwell" which referred only to private petitions. (Cartwright 1817b: 10-12). He later insisted that "It was an illegal act for the House to reject any petitions to which signatures were attached, whether written or printed" (Manchester Observer, 28 March 1818). One reform petition from 1793 had been "laid on a shelf for four-and-twenty years" (Cartwright, 1817b: 31). Printed petitions, Cartwright argued in 1816, were superior to handwritten ones, in that they were accessible, easily propagated, and impossible to alter. (Hampden Club 1816: 41-8). $\quad$ No reform bill had yet been brought forward, but Burdett announced his intention of introducing one in the spring. The wave of petitions to parliament continued, now increasingly using respectful language and making moderate demands, often leaving the nature of the reform to "the wisdom of the House". When Burdett's moment finally came on 20 May all he did was to move that the House of Commons set up a select committee to examine "the state of representation" (Hansard 20 May 1817, vol. 36: 729). Backed by Cochrane, Burdett spoke at length on constitutional history and gained a respectable 77 votes for an inquiry, with 265 against (ibid., 811-12). Among the majority was William Lamb, later a Whig prime minister, but at this time a Tory. When I consider the manner in which these petitions have been prepared and procured ... the speeches which at public meetings have preceded and recommended them, the gross misrepresentations, the delusive promises, the wild hopes, and the excessive exaggerations under the influence of which they have been voted, I cannot consent to consider them as expressing in any 
degree the cool, deliberate, well-understood sense of the people of England (ibid., 790).

Whilst the petitioning campaign had produced an increase in parliamentary support for reform, it also allowed the opponents of petitioning to construct a constitutional case for limiting the manner in which it was exercised. This in turn prompted supporters to articulate a rationale for allowing the voice of the people to be heard in the chamber regardless of the niceties of procedure.

\section{Petitioning and rebellion}

The early rejection of petitions by the Commons was followed by escalation, first to protest and then to rebellion. When the Home Secretary Sidmouth moved the suspension of Habeas Corpus on 24 February, he told the upper house that petitioning for parliamentary reform was a "specious pretext" that concealed "a traitorous conspiracy... for the purpose of overthrowing ... the established government" (Hansard 24 February 1817: 552). From late February petitions for reform mingled with others against the suspension of Habeas Corpus, and the real anger seems to have been channelled into these: the City of London, to take the most prominent example, denounced "a settled design, in the present Ministers of the Crown, to trample upon the Rights of the people, and establish a despotic Government" (CJ, lxxii. 123).

The simultaneous meetings arranged across the country for 10 February to hear the outcome of the petitions were planned by the London ultras as part of an insurgent strategy. In the event they passed off peacefully, adjourned while the organizers considered what to do next. The Manchester meeting went off "very quietly" on a wet day. In Stockport the speakers were warned by Lloyd about seditious speech. Under his stern gaze the militant delegate Henry Rose "was very 
moderate ... Explaining that the Petition had been withdrawn to be revised, he moved an adjournment till the $2^{\mathrm{d}}$ Monday after Sir Francis Burdett had brought before the House his Bill for reform.” His colleague George Bradbury “acknowledged their Petitions were not lawful" and announced the next step agreed by "the Grand Committee at Middleton Chapel": supporters were urged to swamp the authorities with requests for poor relief in order to provoke the rate-paying classes into demanding parliamentary reform. ${ }^{33}$ Even in London, the third Spa Fields meeting (patrolled by magistrates, backed by a heavy military presence) produced only another petition for parliamentary reform from "the distressed and starving Inhabitants of the Metropolis", reinforced by a declaration that the Right of Petition was "the birthright of the People of this Land," and a pointed reminder that James II had lost his throne for violating it. This bold declaration was then prudently signed by the chairman and nineteen others, keeping within the 1661 Act, and presented to the Commons the next day by Lord Folkstone (Hone 1817; CJ, lxxii. 45-6).

One constitutionally-grounded line of action stood out: the remonstrance. As John Gale Jones put it to the London Hampden Club in 1816, "It was for courtiers, slaves, and criminals, to petition, but Freemen and Englishmen should remonstrate, resolve and demand those rights which God and nature gave." (Hampden Club 1816: 24-6). In parliamentary terms a "remonstrance" was simply a petition presented without the correct form of preamble and prayer, a pointless harangue, and such remonstrances were routinely rejected. For some radicals, however, the term acquired a more serious meaning, referring to the "Grand Remonstrance" adopted by parliament in late 1641 . This was a public final notice served on the king which acted both as a manifesto - remonstrating downwards to the people, as one member complained - and as a justification for rebellion (Woolrych 2002: 57-9, 199-202). In 
the aftermath of the failure of the first round of petitions, T. J. Wooler's radical journal Black Dwarf (12 February 1817) derided the whole strategy, demonstrating an awareness of seventeenth-century history.

Bravo! John Bull! Bravo. You have the right of petitioning, have you? And your ancestors obtained it for you, did they? And Hampden bled for the right of petitioning, did he? And Sydney was beheaded, and Russell, for the right of petitioning. ...

They want respectful petitions ... and if you will flatter their vanity, and rely upon their wisdom, faith you may use your right of petitioning as frequently as you please... ... what do you get by it? A clerk ... is set to mutter over your petition. Then it is moved, as there is nothing disrespectful stated, that it do lie on the table.... While you possess the right of petitioning, and they possess the right of neglecting your petitions, it is just the same thing as if you had no right at all ...

Was James petitioned to abdicate his throne? Or was William petitioned to accept the Bill of Rights? No! no! the right of petitioning with your ancestors meant the right of laying their grievances before the highest authority, and demanding, or ENFORCING an attention to their wrongs. Wooler was prosecuted for seditious libel for this passage but was acquitted after arguing that both Magna Carta and the Bill of Rights upheld the constitutional principle that "when a nation is unanimous upon any one point, to petition is absurd, and the members of the administration must of necessity concede that which the people with one consent demand.” (Epstein 1994: 47-51). Cartwright, who was a close associate of Wooler and who supported the Black Dwarf, came up with a legal form of remonstration which exploited the sanction given by the 1661 Act to petitions 
signed by twenty people and accompanied by ten. He translated this into a scheme for a large number of people to carry numerous small petitions from the provinces to London, there to confront the government en masse-a potent mixture of constitutionalism and insurgency. Fresh from the London meeting and contact with Cartwright, William Benbow told a meeting in Manchester on 3 February:

You must be firm and unanimous and petition them again \& again until the Nation is all in one Mind \& then they will not dare to refuse us ... Every 20 of you to sign a separate petition $\& 10$ out of every 20 may carry their own petition up to London. You may do this without asking leave of the magistrates then when there are five hundred thousand men in London will 5 or 6 hundred dare to refuse you? No - if they do we will annihilate them - I mean (checking himself) bring them to order... you may arm yourselves according to your rank \& station with Weapons for your own defence. ${ }^{34}$

Similarly George Bradbury at the Stockport meeting of 10 February, having conceded the illegality of mass petitions, "advised them to petition by Twenties \& carry up their petitions by tens." ${ }^{35}$ An eighteen-year-old orator named John Bagguley earned applause for his own militant line. Speaking in Manchester, with the delegates still in London,

He asked what was to be done if they did not get their request, was they to lie down and die? The People cried no - and I cry No said Baguley. He then stated that the Law says that if the King did not give an answer to the Petition within the Space of 40 days he was liable to be seized and all his Family, and confined in a Prison till he give an answer. Great Shouts took place and clapping throughout the room. 
He repeated the claim two days later and "sought to prove [it] from Magna Charta" but was called to order. His fellow reformer Joseph Bradbury was more circumspect, saying only that in case of rejection "they must adopt such plan as they thought most proper." ${ }^{36}$ On 6 March some five thousand people at a huge indoor meeting were shown the petition they were to take. Bagguley produced three hundred printed copies, and warned: "They must be copied off as they will not be received by the Prince Regent in Print." ${ }^{37}$ He issued further instructions to the intending marchers two days later:

Now you are to class in tens, but 20 of your Neighbours must connect yourselves and write out your Petitions and you all must sign it - and 10 of you must go with it to the Prince Regent. After it is Signed you must wrap it up in a piece of Brown Paper and tie it round your right Arm with a bow of white tape and come with your things on your back with your $10^{\text {th }}$ Man being the chosen Man with the Petition on his right Arm ...

As they set off on 10 March with knapsacks and blankets, Bagguley compared their expedition explicitly to the Peasants' revolt of 1381, when a mass of rebels against the hated poll tax had temporarily extracted concessions from Richard II, only to lose them as soon as they dispersed: "But they only came a little way from London they did not go from Manchester." ${ }^{38}$ His colleague John Johnston, faced with imminent arrest, declared: "We will let them see it is not riot and disturbance we want, it is bread we want, and we will apply to our Noble Prince as a child would to its Father for bread." ${ }^{39}$ Harried by troops and weakened by arrests at Manchester, Stockport, Macclesfield and Ashbourne, the march expired. Subsequent armed risings at Manchester again in late March and at Huddersfield and Pentridge in early June were 
thoroughly penetrated by spies and failed ignominiously in their attempt to set off further marches to London. (Author 2016a, 2016b).

When a batch of eighteen "Blanketeers" - nearly all of them young unemployed men with nothing to lose -were questioned by the Manchester magistrates, they talked of petitioning rather than remonstrance. Asked "What did you go for?" eight mentioned petitioning or "petitioning the Prince Regent". In reply to the question "What were you petitioning for?" only two mentioned "reform of parliament" or "radical reform of parliament", and one said "I was petitioning against the Suspension of the Habius Corpus Act". Nearly all cited distress as their legitimating motivation for petitioning, marrying economic issues and constitutionalism. Their responses, even allowing for the circumspection of offenders under arrest, suggest that belief in the right to petition for redress of intolerable grievances was deeply rooted in society. ${ }^{40}$ The Manchester magistrates for their part prepared committals under the 1661 Act against tumultuous petitioning, and urged another argument upon the Home Office:

I cannot help thinking that such an assemblage which was naturally calculated to create Terror to a very great Degree would independently of the Statute have rendered it a Breach of the Peace at Common Law ... notwithstanding the act which is used in preparing the Petitions they seem to have very strongly the Character of Rebels. ${ }^{41}$ The Attorney-General had already come to the same conclusion, advising prosecution under the 1661 Act and also finding that it was illegal to assemble in 'numbers to such an extent as to excite terror and apprehension'. In the end the government baulked at putting this to the test, and instead the local radical leaders were interned under the Habeas Corpus Suspension Act until the crisis was safely over. (Lobban 1990, 333-4). Whatever their views on the real purpose of the petitioning campaign, 
the authorities were unwilling to risk prosecuting people just for petitioning. But by the same token most reformers, however bitter their views about the practical value of petitioning, were unwilling to risk jeopardizing their right to petition by ignoring its rules and conventions.

In 1816-17 petitioning and rebellion were mutually dependent strategies for obtaining parliamentary reform: petitioning depended upon the threat of rebellion for its effectiveness, while rebellion depended upon petitioning for its legitimacy. Both strategies drew on constitutional precedents, , and the threat of rebellion was later successfully deployed by the Whigs to force through the 1832 Great Reform Act. While government held out comfortably in 1817 against demands for parliamentary reform, the right to petition was much more difficult to rebut. Attention was accordingly directed not to the right of petitioning but to its disorderly consequences and to its apparent abuse by ultra-radicals as a cover for insurrection. (Lobban 1990) Consequently the first emergency legislation of 1817 was not, as in 1795, a suspension of the right to meet but rather a suspension of Habeas Corpus. A Seditious Meetings Act, which banned unauthorised political assemblies of more than fifty people such as had been used for mass petitioning, followed, but it was also temporary and expired in July 1818.

\section{Petitioning secured}

As Parliament moved to restore Habeas Corpus in January 1818, reformers were ready with more petitions. The first issue of the radical Manchester Observer (3 January 1818) opened with a leader on petitioning. The government, it complained, was threatening people with a $£ 100$ fine or 3 months' imprisonment for petitioning with more than 20 signatures - that is, under the 1661 Act. But, it pointed out, petitions were exempt from postage charges and their organization could act like the 
cell system of the old corresponding societies, subdividing every nineteen names to multiply through neighbourly networks. The million signatures collected in 1817 would now translate into 50,000 petitions, occupying the House for years until it had to give in. On 28 January Burdett presented to the Commons a reform petition of twenty signatures from the citizens of Bath, "the number allowed to assemble under the severest Legislative Acts on the subject", followed by eight more the same (Hansard 28 January 1817: 88-90). On 3 March, the anniversary of the presentation of over five hundred petitions in 1817, Samuel Romilly presented 45 petitions of 20 signatures from the inhabitants of Bristol. Cochrane declared that "he was confident that petitions would pour in on them, signed by tens and hundreds of thousands. He had a hundred petitions from Yorkshire, forty-five from Leeds, fifty-four from Bristol, and five from Newcastle-upon-Tyne" (Manchester Observer, 7 February 1818, 7 March 1818). Twenty-one petitions of twenty signatures each came from Rochdale (Manchester Observer, 2 May 1818). Altogether 1,481 small petitions for parliamentary reform were submitted to the Commons in 1818, two-thirds of the total of all public petitions for that year and double the total for 1817 (if not double the weight). ${ }^{42}$ (Cochrane by this time had changed his mind over the issue of printed petitions, telling a reform meeting at Palace Yard in March that 'he did not conceive them to be the spontaneous opinion of those who signed them. It was a bad system of petitioning... The local grievances of people were always best expressed in their own words'. Hunt and Cartwright did not agree.) (Manchester Observer 28 March 1818). The petitions again failed to move the Commons, and Hunt joined with the London radicals for a meeting in Westminster Palace Yard in September which pronounced the petitioning strategy dead. It resolved instead to remonstrate with the Prince Regent to dismiss the 'junta', reminding him of the 
English right to resist tyranny exercised against Charles I and James II. (Belchem 1985, 86-7). The Manchester Observer opened its 1819 campaign by declaring that appeals to government "should no longer be styled Petitions, but REMONSTRANCES. . . . the boasted right of petition, which in all cases is a nullity or an absurdity, was only understood by our ancestors, as the right of approaching the throne, with our complaints, and to obtain an answer, or a redress... WHY THEN PETITION? Why not REMONSTRATE BOLDLY and firmly?" (Manchester Observer, 16 January 1819) The sovereignty of the people, declared the paper, amounted to more then 'the sovereign right of begging' (Manchester Observer 9 Feb. 1819). Petitioning retained its appeal for some. A meeting in the radical stronghold of Royton in February voted in favour of petitioning after hearing from the veteran local reformer John Kay that 'a Petition ... would remain before the House and the public, whereas a Remonstrance would be tossed aside and never seen more.'43 A declaration addressed to the reformers of Wigan in July 1819 recalled the disappointments of 1817 .

The farce of petition is over. Paper and parchment will never again be wasted on so stupid an object as petitioning a should-be House of Commons to reform itself. A million and a half men have petitioned for reform. The greater part of the petitions have been rejected, and nine have been attended to ... The spirit of the country will never again condescend to pray to those whom the people themselves ought to delegate. ${ }^{44}$

The Birmingham meeting of July 1819 planned to elect its own members of parliament. Cartwright however persuaded the organisers to reign back and instead appoint a single "legislatorial attorney" whom he described as "a petition in the form 
of a living man, instead of one on parchment or paper." (Cartwright, 1826, 164-9) Such representatives, declared T. J. Wooler, 'cannot be got rid of by being laid on or put under their table.' (Belchem, 1981, 13-14). The famous meeting at St Peter's Field, Manchester, on 16 August 1819 was at first intended to elect another attorney, but the organisers prudently backed down and readvertised the meeting for more legal purposes. The mass platform campaign was nonetheless decisively halted at Manchester by the cavalry attack known as "Peterloo". The emergency legislation that followed, the Six Acts of 1819, repeated the restrictions on meetings introduced in 1817 and added others on the conduct of processions and the freedom of the press, to prevent a popular movement from turning the right to petition into the right to resist. (Epstein 1994, ch.1; Belchem 1985; Pickering 2001). ${ }^{45}$

Amid all the attention paid to the repressive nature of the Six Acts, one significant concession has gone unnoticed: the right to petition. MPs who strongly supported the government in the Commons debates still found it necessary to declare their support for the right to petition, understood to include the right both to meet and to deliberate. For opposition MPs to suggest that this right was under threat, complained Sir Valentine Blake, "was an extraordinarily unnecessary course. Who is it that does not admit the right?" His objection was only to intimidatory mass petitioning (Hansard 26 November 1819: 340-1). William Plunket, while opposing the call for an enquiry into Peterloo, averred:

The right of the people of this country to meet, for the purpose of expressing their opinions on any subject connected with their own individual interest, or with the public welfare, was beyond all question; it was a sacred privilege, belonging to the most humble, as fully as to the highest subject in the community. (Hansard 23 November 1819: 129) 
Even the implacable George Canning, speaking after the general election of 1820, asked himself: "Do I deny then, the general right of the people to meet to petition, or to deliberate upon their grievances? God forbid!" What he did not accept, he explained, was "a right to collect together countless multitudes, to discuss the question of Parliamentary reform; to collect them when they would, and where they would, without consent of Magistrates, or concurrence of inhabitants, or reference to the comfort and convenience of the neighbourhood." (Canning,1820). These qualifications about mass action were important at the time, but in the longer run it was the concession of principle that was the more significant. The 1819 Seditious Meetings Act expired in 1826, saving the clause banning unauthorised political meetings within one mile of parliament which continued until 1986. This allowed the 1830-2 campaign for the Great Reform Act to succeed through a mass mobilization not too different from what had been attempted in 1816-19, but this time under middle-class leadership. The constitutional tradition of petitioning with menaces proved to be a real political asset. Whereas in France serious change was equated with revolution and the right to petition was the preserve of the timid, asserted only in pursuit of incremental political gains, in Britain the history of radical petitioning gave Chartism and later movements a confidence in mobilizing great masses of citizens to stand up for democratic principles. ${ }^{46}$ (Agnés 2013: 66; Miller 2017)

\section{Conclusion}

The radical campaign of 1816-17 stretched the customary limits of the petitioning process in several important ways. It challenged the right of the authorities to control petitions offered in the name of the public. It expanded the accepted right of interest groups to petition on economic grievances into a general right of "the people" to 
demand political solutions for their distress. In doing so it brought the legitimacy of desperation to bear on the procedures of parliamentary petitioning, justifying the resort to remonstrance and resistance. It also expanded the pool of people who claimed a legitimate interest in government to include every adult male, and so fed the case for democracy. It mobilised such large numbers of people - some $25 \%$ of adult males - that it became possible to represent the petitioning process as an historic dialogue between governors and governed, comparable to the constitutional conventions of 1215 and 1688-9. Despite the sharp contest over forms, played out so brutally at Peterloo, the right to petition, and to meet to petition, was in the end successfully asserted, defended, and conceded in principle to the unenfranchised population. The practical consequences had to await the revival of the reform movement in 1830-2, by which time it was taken for granted. But the right of the unenfranchised masses to take part in political petitioning was successfully established by the radical movement in the years 1816-20, well in advance of the advent of parliamentary democracy, with consequences for English political culture which remain with us today.

The research for this article was made possible by a British Academy Small Research Grant, 'The English Reform Movement of 1816-17: Understanding the Home Office disturbances papers' (SG 130774). I would like to thank Frank O'Gorman, Henry Miller, Malcolm Chase and an anonymous reviewer for valuable comments and criticisms, while I of course remain responsible for the final result. The article owes more than might be apparent to my participation, forty years ago, in the late Professor Austin Woolrych's special subject at Lancaster University on 'The English Revolution'. 


\section{References}

Agnes, Benoit (2013) "A Chartist Singularity? Mobilizing to Promote Democratic Petitions in Britain and France, 1838-1848.” Labour History Review 78: 51-66.

Author (2009) "French Revolution or Peasants' Revolt? Petitioners and Rebels from the Blanketeers to the Chartists", Labour History Review 74: 6-26. (2016a), “"To the Last drop of My Blood': Politics and Melodrama in Early Nineteenth-Century England”, in K. Newey, J. Richards \& P. Yeandle eds., Performance, Politics and Popular Culture in Nineteenth-century Britain. Manchester: Manchester University Press: 21-43.

(2016b), 'The Risings of 1817', the Luddite Memorial Lecture 2016, University of Huddersfield, http://www.huddersfieldhistory.org.uk/events2/luddite-lecture/

Bamford, Samuel ([1844] 1967), Passages in the Life of a Radical. London: Cass.

Belchem, John (1981), "Republicanism, popular constitutionalism and the radical of in early nineteenth-century England." Social History 6, 1. (1985) 'Orator' Hunt: Henry Hunt and English Working-class

Radicalism. Oxford: Oxford University Press.

Bohstedt, John (2010) The Politics of Provisions. Aldershot: Ashgate.

Bradley, James (2007) "Parliament, Print Culture and Petitioning in Late EighteenthCentury England.” Parliamentary History 26: 96-111.

Canning, George (1817) Speech of the Rt. Hon, George Canning delivered at Liverpool, March 1820. London: P. Kelleher.

Cartwright, John (1817a) A Bill of Rights and Liberties. London. (1817b) Letters to the Lord Mayor. London.

Cartwright, F. D. ed. ([1826] 1969) The Life and Correspondence of Major Cartwright, 2 vols. New York: Kelley.

Chase, Malcolm (1998) The People's Farm: English Radical Agrarianism, 1775-1840. Oxford: Oxford University Press. (2000) Early Trade Unionism. Aldershot: Ashgate.

Colley, Linda (1992) Britons. New Haven \& London: Yale University Press.

Cornish, Rory T. 'Cartwright, John (1740-1824)', Oxford Dictionary of National Biography, Oxford University Press, 2004 http://www.oxforddnb.com/view/article/4817, accessed 25 Nov 2016.

Davis, H. W. (1926) “Lancashire Reformers 1816-17”. Bulletin of the John Rylands Library, 10: 47-79. 
Eckersley, Rachel (1999) The Drum Major of Sedition: the Political Life and Career of John Cartwright (1740-1824). PhD thesis, University of Manchester.

Epstein, James (1994) Radical Expression: Political Language, Ritual and Symbol in England, 1790-1850. Oxford: Oxford University Press.

Handley, Robin (1986) "Public Order, Petitioning and Freedom of Assembly", Journal of Legal Studies 7: 123-55.Hampden Club (1816) A Full Report of the Meeting of the Hampden Club 15 June 1816, upon the Subject of Parliamentary Reform. London: William Hone.

Hampden Club (1822) A Collection of Reports of the Proceedings of the Hampden Club. London: British Library, 8135.f.19. [This is a bound item unique to the BL so I have given the shelfmark]

Hansard's Parliamentary Debates, 1817.

Harris, Tim, ed. (2001) The Politics of the Excluded, c. 1500-1850. Basingstoke: Palgrave.

Hone, William (1817) Full Report of the Third Spa-Fields Meeting. London.

Huish, Robert (1836), History of Henry Hunt, 2 vols. London: John Saunders

Knights, Mark (2009) "Participation and Representation Before Democracy: Petitions and Addresses in Britain", in Ian Shapiro et al. eds., Political Representation.

Cambridge: Cambridge University Press: 35-57. (2012) "The 1780 Protestant Petitions and the Culture of Petitioning", in Ian Haywood and John Seed, eds, The Gordon Riots. Cambridge: Cambridge University Press: 46-68.

The Journals of the House of Commons, 1817, vol. 1xxii at http://parlipapers.proquest.com/parlipapers

Lobban, Michael (1990), "From Seditious Libel to Unlawful Assembly: Peterloo and the Changing Face of Political Crime c. 1770-1820." Oxford Journal of Legal Studies 10: $307-52$.

Lockley, Philip (2013) Visionary Religion and Radicalism in Early Industrial England. Oxford: Oxford University Press.

Miller, Henry (2017) "Petitioning and Demonstrating", in D. Brown, G. Pentland and R. Crowcroft (eds), The Oxford Handbook of Modern British Political History, 18002000. Oxford: Oxford University Press.

Miller, Naomi C. (1968) “John Cartwright and Radical Parliamentary Reform, 18081819.” English Historical Review 82: 205-28. (1974) "Major John Cartwright and the Founding of the Hampden

Club.” Historical Journal 17: 615-19. 
Navickas, Katrina (2009) Loyalism and Radicalism in Lancashire 1789-1815. Oxford: Oxford University Press.

O'Gorman, Frank (1986) “The unreformed electorate of Hanoverian England.” Social History 11, $133-52$.

O’Gorman, Frank (1989) Voters, Patrons and Parties. Oxford: Clarendon Press 'Operator' (1817), Petitioning Weavers Defended. Manchester.

Parsinnen, T. M. (1973), "Parliament and Anti-Parliament in British Radical Politics, 1771-1848.” English Historical Review 88: 504-33.

Peacey, Jason (2016) "The Parliamentary Context of Political Radicalism in the English Revolution”, in L. Curelly and N. Smith eds., Radical Voices, Radical Ways. Manchester: Manchester University Press: 151-68

Pearson, Charles (1820) The Substance of a Speech Delivered by Charles Pearson at the Court of Common Council of the City of London on the $6^{\text {th }}$ of December 1819.

London: Thomas Dolby.

Philips, John (1980), "Popular Politics in Unreformed England." Journal of Modern

History 52: 599-625.

Pickering, Paul (2001) "And your petitioners \&c.: Chartist Petitioning in Popular Politics, 1838-48.” English Historical Review 116: 368-88.

Poole, Steve (2000) The Politics of Regicide in England, 1750-1850. Manchester: Manchester University Press.

Radcliffe, William ([1828] 1974) On the Origins of the New System of Manufacture, Commonly Called "Power-Loom Weaving". Clifton, NJ: Augustus Kelley.

Thompson, E. P. (1991) Customs in Common. London: Merlin.

Thorne, R., ed. (1986) The History of Parliament: the House of Commons 1790-1820, at http://www.historyofparliamentonline.org/

Vernon, James, ed. (1996) Re-reading the Constitution. Cambridge: Cambridge University Press.

Waddell, Brodie (2016) 'Was Early Modern England a Petitioning Society?', in Brodie Waddell (ed.) Addressing Authority: An Online Symposium on Petitions and Supplications in Early Modern Society, https://manyheadedmonster.wordpress.com/2016/11/01/addressing-authority/

Wood, Andy (2002) Riot, Rebellion and Popular Politics in Early Modern England. Basingstoke: Palgrave.

Woolrych, Austin (2002) Britain in Revolution. Oxford University Press. 
Zaret, David (2000) Origins of Democratic Culture. Princeton University Press..

Ziegler, Philip (1965) Addington. London: Collins. 
1 The National Archives, Home Office disturbances papers, HO 42/150 fols. 260-75 Prescot \& Lloyd to Home Office 20-21 May 1816; HO 42/151 fol. 507, Lloyd to Sidmouth 25 June 1816.

${ }^{2}$ HO 42/151 fols 21, 131, 139, 338, Fletcher to Sidmouth 27 May \& 1 June 1819, Hay to Sidmouth 1 May 1818, \& Earl of Derby to Sidmouth n.d. [June 1817].

${ }^{3}$ HO 42/152 f. 645 Lloyd to Beckett 27 August 1816.

${ }^{4}$ HO 42/152 fols 643-7, Lloyd to Beckett 27 \& 29 Aug. 1816 and enclosures.

${ }^{5} \mathrm{HO} 42 / 153$ f. 353 Lloyd to Beckett, 18 Sept. 1816.

${ }^{6}$ HO 42/153 f. 495-9, Fletcher \& Lloyd to Home Office 26 Sept. 1816 \& enclosures.

${ }^{7}$ HO 42/153 f. 447-51, Lloyd to Home Office 6 Oct. 1816 \& enclosures.

${ }^{8}$ Lancashire Record Office DDHU 53/55, 25 Feb. 1817.

${ }^{9} \mathrm{HO} 42162$ fols 350-2. Evans to Sidmouth 18 March 1817.

$10 \mathrm{HO} 42 / 154$ f. 501.

$11 \mathrm{HO}$ 40/5/4a f. 1338, report of 6 March 1817.

${ }^{12}$ Report of the Public Meeting, Manchester, Oct. $28^{\text {th }}$, 1816, Manchester Central

Library H4445, and TNA TS 24/3, 71.

${ }^{13}$ HO 40/3/2 fols 784-7, Knight to Kay 21 Nov. 1816, enclosure.

14 Cartwright to John Shuttleworth, 24 Feb. 1813, Manchester Central Library BR f.324.94273 S3. A petition from Rochdale was also reported to have been abandoned because of threats.

${ }^{15}$ HO 40/3/5 f. 942, Chippendale 15 Dec. 1815; HO 40/3/1 fol. 724 Cartwright to John Taylor, Blackley, 23 Nov. 1816; Documents Concerning the Formation of Hampden Clubs 1816-17, Manchester Central Library.

${ }^{16}$ HO 40/9/5 f. 542-7, Hampden Club pamphlet, title page missing, c. Apr. 1815. A ms. note from Cartwright indicates that his Secretary, Thomas Cleary, brought the pamphlet to Burdett for approval on 15 Apr. 1815.

${ }_{17} \mathrm{HO}$ 40/3/5 f. 942, Chippendale 15 Dec. 1816.

18 HO 42/153 f. 376.

19 HO 42/153 f. 371, Chippendale 4 Sept. 1816.

${ }^{20} \mathrm{HO}$ 40/3/1 f. 702, Chippendale 7 Dec. 1816.

${ }^{21} \mathrm{HO} 42 / 157$ f. 182.

${ }^{22} \mathrm{HO} 42 / 157$ f. 160.

${ }^{23} \mathrm{HO} 42 / 158$ f. 669.

${ }^{24} \mathrm{HO} 40 / 3 / 1$ f. 728, Chippendale 6 Jan. 1817.

${ }^{25}$ HO 42/158 f. 670, George Holmes, 9 Jan. 1817.

${ }^{26} \mathrm{HO} 42 / 198$ f. 148, Chippendale to Fletcher, 23 Jan. 1817.

27 HO 40/10/2 fols 115-23; HO 40/3/1 f. 734, Chippendale 4 Jan. 1817; To the People of England, TNA TS 24/3, 72-3; Manchester Political Register, 4 January 1817.

${ }^{28}$ HO 40/3 f. 731, Chippendale 13 Jan. 1817; HO 42/158 f. 126, Chippendale 15 Jan. 1817.

${ }^{29} \mathrm{HO} 42171$ f. 184, Chippendale to Fletcher 6 Feb. 1817 (enclosure); HO 42/158

fols 148-9, Chippendale 23 Jan. 1817.

30 British Library Add, MS, 27809, Place Papers ii.

${ }^{31} \mathrm{HO} 42171$ f. 183, Chippendale, 6 Feb. 1817.

32 Manchester Observer 18 April 1818. 
${ }^{33}$ HO 42159 f. 52, John Lloyd, 10 Feb. 1817.

${ }^{34}$ HO 42159 f. 28, information of Sergeant John Oldham, 8 Feb 1817.

35 HO 42159 f. 52, John Lloyd, 10 Feb. 1817.

${ }^{36} \mathrm{HO}$ 42/164 f. 155-82, 'No. 2', 4 April 1817.

${ }^{37} \mathrm{HO}$ 40/5/4a f. 1350, John Livesey, 7 March 1817.

38 HO 40/5/4a f. 1360, Anon. 10 March 1817.

39 Ibid.

${ }^{40} \mathrm{HO} 42 / 164$ f. 43.

${ }^{41}$ HO 42162 fols 350-2, Evans to Sidmouth, 18 March 1817.

42 Thanks for this information to Henry Miller, the result of a count in the Commons

Journal.

${ }^{43} \mathrm{HO}$ 42/184 f. 329, Chippendale, 9 Feb. 1819.

${ }^{44}$ HO 42/189 f. 129 handbill 'Britons be free!'

45 This will be covered in my forthcoming book, Peterloo: the English Uprising

(Oxford University Press).

${ }^{46}$ See Malcolm Chase, 'What did Chartism Petition for?' elsewhere in this journal. 